\title{
Conflicts and Conflict Situation Settlement of Children of 5-6 Years Attending Pre-school Educational Institution
}

\author{
Medera Halmatov \\ Department of Preschool Education, Faculty of Education, Ağrı İbrahim Çeçen University, Turkey
}

Copyright $(2018$ by authors, all rights reserved. Authors agree that this article remains permanently open access under the terms of the Creative Commons Attribution License 4.0 International License

\begin{abstract}
Relationships with others are not always easy and harmonious. Already in the kindergarten group, there are many conflicts between children, which are the result of a distorted way of developing interpersonal relationships. It is the most important task of the educator, parent and psychologist - to recognize these dangerous trends and help the child overcome them on time. Obviously, every aggressive act has a certain cause and it is carried out in a specific situation. Consideration of the situations in which aggressive behavior is the most often manifested is necessary to understand the direction of aggressive behavior, its causes and purposes, which may shed a light on its motivation. The purpose of the study: situations that cause conflict among children of 5-6 years in pre-school institutions, the attitude of children to conflict situations and the resolution of these conflict situations without the intervention of adults. In order to identify the main causes of the conflicts between children of preschool age, we observed the behavior of children during various games, that is, during games that children organized themselves during period in the kindergarten. To identify the relationship of children to conflict situations, the researcher created an observation sheet that includes 5 questions. The experimenter observed from the side and recorded all manifestations of conflict behavior of preschool children.
\end{abstract}

Keywords Children, Conflict Situation, Game

\section{Introduction}

Relations with people give birth to the most joyful and most dramatic, but always acute and meaningful experience. Attitude to other people is built and most intensively developed in the childhood. Moreover, the main space for the birth of such relationships is in the sphere of communication with peers. Studies show that by the end of preschool age, there is a more or less specific type of attitude towards a peer that either ensures normal communication and cooperation, or leads to difficulties in communication and the occurrence of frequent conflicts with other children. Problems and conflicts between children give rise to hard feelings (resentment, envy, anger, etc.). Such an experience of childhood can later become a source of serious interpersonal and intrapersonal problems of an adult [1].

Practically, in each group of kindergarten the complex and sometimes dramatic picture of interpersonal relations of children reveals. Emotional tension and propensity to conflict in the sphere of children's relationships are much higher than in the sphere of communication with an adult. Adults sometimes do not suspect about wide range of feelings and relationships that children experience; do not attach much importance to childish quarrels and offenses. Meanwhile, the experience of the first relationship with peers is the foundation upon which further development of the child's personality is built. Conflict situation develops into conflict only with the joint actions of the child and peers. A similar situation arises in cases where there is a contradiction: between the demands of peers and the objective capabilities of the child in the game.

One of the main ideas advocated by L. S. Vygotskii, is that the characteristics of a troublesome child should not be considered in static, as the sum of his "defects", but in dynamics. L. S. Vygotskii calls for the transfer of the center of gravity from the study of external manifestations to the content of psychological mechanisms, to move from the consideration of a "defect" in behavior as an end in itself to changes that occur in the development process and find themselves in these symptoms. According to the scientist, cultural forms of behavior are the essence of the reactions of the individual. Studying them, we are not dealing with individual processes, but with the personality as a whole. Tracing the cultural development of mental 
functions, we draw a path of the development of the personality of a child [2].

The problem of conflict behavior in the pre-school age was addressed by many researchers [3], A. V. Zaporozhets [4], A. N. Leontiev [5], A. V. Morozov [6], D. B. Elkonin [7], P. M. Iakobson [8] L. S. Vygotskii, D. B. Elkonin, A.V. Zaporozhets, Ia. L. Kolominskii and others. They believe that in the pre-school age, conflicts most often arise about the game, as it is the leading activity of pre-schoolers, and also note that preventing conflict behavior of pre-school children presupposes the child's comprehension of himself; development of personal mechanisms of behavior; formation of primary ethical bodies and moral evaluation on their basis; the emergence of new motives for actions and activities.

Roiak A.A. gives the following definition: "Conflict is a form of social interaction between two or more subjects, arising from the discrepancy of desires, interests, values or perceptions" [9]. Conflict is understood as the most acute way of resolving significant contradictions that arise in the process of interaction, consisting of a counteraction of the subjects of the conflict and usually accompanied by negative emotions [10].

In one of the studies, Ia. L. Kolominskii and B.P. Zhiznevskii identified typical causes of conflict between children of different ages. According to the data received, children of older pre-school age have conflicts more often arisen because of the distribution of game roles, as well as about the correctness of the game actions [11].

A. I. Anzharova studied some difficulties in the relations of children, and first of all the phenomenon of childish isolation, which is based on deep violations of the communication process [12]. The subject of the study of A. A. Roiak is the children's unpopularity. The author attributes the need for its correction to the importance of the child's need for recognition development, which, in conditions of unpopularity, is frustrated [9].

Kalinina R.R. notes that it is very important to diagnose the psychological conflict of pre-school children at the early stages of its development. Only at this time it is possible to correct it: teaching these children to playing skills, improving their ways of building relationships with peers, combined with a reorientation of the current peer opinion, further organization of gaming interaction can restore faith in themselves, joyful mood, increase the initiative to start contacts [13].

The development of interpersonal relations of children in pre-school age is a complex intertwining of two principles regarding the relation of the child to himself and to others. So, how does the child's attitude to other children change during the pre-school age. The received empirical data confirm the dynamics described by D.B. Elkonin: younger children have conflicts most often because of toys, middle-aged children - because of roles, and elders - because of the rules of the game [10].

The studies revealed the following ways of children influencing other participants in the game conflict:

1. Physical exposure - this includes actions where children, especially younger ones, push each other, fight, and also take away toys, scatter them, occupy someone else's place in the game, and so on [14].

2. Mediated exposure - in this case, the child deals with the rival through the other people. This includes complaints to educator on a peer, crying, screaming in order to attract the attention of an adult, as well as an exposure with the help of other children involved in the conflict to confirm their claims.

3. Psychological exposure - these are ways of influencing a rival which are addressed directly to him, but this is done at the level of crying, screaming, stomping with feet, grimacing, etc., when the child does not explain his claims, but exerts a certain psychological pressure on the opponent.

4. Verbal exposure - in this case, the means of influence is a speech, but these are mainly various instructions to the opponent, what he should do or what he should not do. These are statements like "Give it back," "Go away," a kind of labeling your own actions - "I'll be a teacher," refusing to take the action required by the partner, as well as questions that require a specific answer, for example, "Where is your car?". In the latter case, a peer also has to perform a certain action, not a subject action, but a speech action.

5. Threats and sanctions - this includes statements in which children warn rivals about possible negative consequences of their actions, for example, "I'll tell"; threats of destruction of the game - "I'm not going to play with you", threats of breaking the relationship as a whole - "I'm no longer friends with you", as well as various interjections and words uttered with threatening intonation: "Well!", "Oh, so! "," Understood?" and so on.

6. Arguments - the statements using which children try to explain, justify their claims or show the illegitimacy of the rivals' claims are included here. These are statements like "I'm first", "It's mine," statements about my desire - "I want too," an appeal to his/her position in the game - "I'm a teacher and I know how to teach", rhetorical questions like "Why did you break everything up? ", " What did you come here for? ", which clearly shows the negative evaluation of the partner's actions, as well as direct assessments of own actions and actions of the rivals (" You cannot play "," I know better how to cure ") and various offensive nicknames, teasers, etc. The same group includes cases where children try to appeal to certain rules, for example, "You have to share", "Seller should be polite," and so on [15]. 
Considering the development of communication between children and their peers, we can trace the way of attitudes formed towards other children. From 2 to 7 years, interpersonal relations of children have a quite complex path of age development, in which there are three main stages.

1. At the stage from 2 to 4 years, the interaction of children is an emotional-practical interaction [16].

The distinctive feature of this age communication is the imitation of the actions of a peer. Repetition of movements behind a peer brings an incomparable emotional uplift to kids (they laugh, scream, jump, etc.). These actions are devoid of a business purpose.

2. For younger pre-schoolers, the most common is an indifferent-benevolent attitude towards another child.

Three-year-old children are indifferent to the achievements of a peer and to the assessment of him by an adult. At the same time, usually, at the suggestion of an adult, they easily solve problem situations "in favor" of others: they give way to the queue in the game give their items or toys to friends.

3. A decisive change in attitude towards a peer occurs in the middle of pre-school age. In 4-5 years the picture of interaction of children essentially varies. In the middle group, emotional involvement in the actions of another child increases dramatically. The reactions of children to adult assessment also become more acute and emotional. The success of peers can cause a grief of children, and their failures cause an undisguised joy. At this age, the number of children's conflicts significantly increases; such phenomena as envy, jealousy, resentment towards a peer arise.

All this allows us to talk about a deep qualitative restructuring of the child's relationship to a peer. The pre-schooler begins to treat himself through another child, who becomes the object of constant comparison with himself. There is a sense of pride in their achievements, their desire to demonstrate them, to receive a praise [17].

By age of 6 , the emotional involvement in the activities and experiences of a peer significantly increases, there is a disinterested desire to help a peer, give something or give way to him. Gloating, jealousy, and competition are less frequent and less acute than in the five-year-old age.

This is in general terms the age-related dynamics of the development of attitudes towards a peer in the pre-school age. However, it is not always realized in the development of specific children. It is known that there are significant individual differences in the attitude of a child towards his peers, which in many respects determines his state of health, his position among others and the peculiarities of his personality. Of particular concern are the problematic forms of interpersonal relations.

There are different variants of the conflict between the child and his peers. Among them are the increased aggressiveness, sensitivity, shyness and demonstrativeness of pre-school children.

Aggression in general terms is understood as a purposeful infliction of physical or mental harm to another person [18].

Aggressive behavior already in the pre-school age takes a variety of forms. In psychology, it is common to point out the verbal and physical aggression, each of which can have direct and indirect forms. Observations show that all these forms of aggressiveness exist already in the kindergarten group.

\section{Verbal Aggression}

1. Indirect verbal aggression is directed at accusation or threats of/to a peer, which are carried out in various utterances [19].

At preschool age, this may be:

- complaints ("He popped me", "But she did not remove the toys", etc.);

- a demonstrative cry aimed at eliminating a peer ("Go, I got bored", "Do not bother");

- aggressive fantasies ("If you do not obey, a policeman will come to you and put in jail"; "I'll catch you up, bite you, put on a plane and send to a high mountain, and you'll be there alone"),

2. Direct verbal aggression is an insult and verbal form of humiliation of another. Traditional child forms of direct verbal aggression are:

• $\quad$ teasers ("sneaky-pants", "piggy", "glutton");

• $\quad$ insults ("freak", "dumbass").

\section{Physical Aggression}

1. Indirect physical aggression is aimed at bringing some material damage to another through direct physical action. At pre-school age, this can be:

- the destruction of the products of another's activities (for example, one child brakes the building out of the cubes of another, or the girl smeared with paint the drawing of her friend);

- destroying or damaging other people's things (for example, a boy strikes on a comrade's table and smiles at the sight of his indignation, or the child throws a strange machine onto the floor and watches with satisfaction the horror and tears of its owner).

2. Direct physical aggression is a direct attack on another and inflicting physical pain and humiliation on him. It can take a symbolic and real form:

- symbolic aggression represents threats and intimidation (for example, one child shows a fist to another or scares him);

- direct aggression - a direct physical attack (fight), which can include bites, scratching, grasping for 
the hair, using as weapons the sticks, dice, etc. [20]. Most often the overwhelming majority of children have direct and indirect verbal aggression - from complaints and aggressive fantasies ("I'll call the bandits, they'll beat you and tie you up") to direct insults ("fat woman", "fool", "sneak and whiner"). Some children have cases of physical aggression - both indirect (the destruction of the products of another's activities, the destruction of other people's toys, etc.), and direct (children beat their peers with a fist or a stick on the head, bite, etc.).

This data gives grounds to believe that the main distinguishing feature of aggressive children is their attitude towards their peers. Another child stands for them as an opponent, as a competitor, as an obstacle that needs to be eliminated.

As you can see, most manifestations of aggressive behavior are observed in situations of protection of their interests and upholding their superiority, when aggressive actions are used as a means or as a tool for achieving a specific goal. Accordingly, the maximum satisfaction for children is obtained by obtaining the desired goal, whether it is peer's attention or an attractive toy, after which aggressive actions cease [21].

Particularly, vividly selfish tendencies are manifested in the behavior of children with authoritarian motives, in particular, striving for an absolute affirmation in the game on the featured part. Even more obvious are the tendencies, when such a child succeeds in asserting his position as a leader.

The authoritarian leader - child, who builds a leadership game based on the principles of domination-subordination. Actively striving to play, such a child is actually driven only by the need for self-assertion. The general formula for motivating a children's game - "not to win, but to play" here turns out to be distorted: not to play, but to win, to defend your place as the leader. That is why they prefer to unite with the poorly initiative, conformal children of the group who voluntarily accept secondary part, the joint game ceases to attract them if there is no possibility of "dictating" [22].

Fopel K. notes that the existence of two contradictory plans for children's relationships in the authoritarian type of leadership of the game: one - external, prosperous, another - deeply conflictual - poses a serious danger both for the development of the personality of the leader and his partners [23].

Among the situations provoking the aggressiveness of children, the following are distinguished:

- Attracting peer's attention

- Infringement of the merits of another in order to emphasize own superiority

- $\quad$ Protection and Revenge

- Aspiration to be the leader

\section{- $\quad$ The pursuit of the desired object}

O. E. Smirnova points out four types of children: conflictual, conflict-free, children seeking to attract attention and children avoiding contacts. Despite the differences in behavior, the basis for interpersonal conflicts is similar. But since the psychology of a child in the pre-school age is volatile, it becomes possible to overcome various deformations in the relations of children with peers and to remove the child's fixation from himself, thereby helping the child of pre-school age to build positive relationships with peers [24].

Most manifestations of aggressive behavior are observed in situations of protecting their interests and upholding their superiority, when aggressive actions are used as means to achieve a certain goal. Consequently, the maximum satisfaction children receive when they get the desired goal - whether it is peer's attention or an attractive thing - after which aggressive actions cease. Thus, in most cases, the aggressive actions of children are instrumental or reactive. At the same time, some children have aggressive actions that do not have any purpose and are aimed solely at causing harm to another. For example, a boy pushes a girl into the pool and laughs at her tears, or the girl hides the slippers of her friend and watches with pleasure at friend's experience. The physical pain or humiliation of a peer causes these children's satisfaction, and aggression acted as an end in itself. Such behavior may indicate the child's inclination to hostility and cruelty, which naturally causes particular anxiety [25].

The study was expected to clarify such issues as:

1. which situations cause conflict between children of 5-6 years in pre-school,

2. the attitude of children to conflict situations,

3. solving conflict situations without the intervention of adults.

\section{Method}

To clarify the causes of conflict of children of secondary pre-school age, a method of observation was used. The method of observation is indispensable in the primary orientation in children's relationships. It allows you to describe the specific situation of children's interaction, gives many new and interesting facts that reflect the child's life in natural conditions for him. In order to identify the main causes of conflicts between pre-school children, we observed the behavior of children during various games, that is, during games that children organized themselves during their stay in the kindergarten. To identify the relationship of children to conflict situations, the researcher created a observation sheet that includes 5 questions. The experimenter observed from the side and recorded all manifestations of conflict behavior of pre-school children. Criteria and evaluation of results: negative conflict behavior was assessed by the following criteria: 
- causes of conflicts;

- features of children's behavior in a conflict situation;

- the severity of conflicts;

- methods to resolve conflict situations;

\subsection{Sampling}

The study was attended by children of 5-6 years age attending the state kindergarten in the city of Agri, in the number of 42 people, including 18 boys and 24 girls.

\subsection{Ethical Approval}

This study has been approved by the Human Experiment Local Ethics Committee of Ağrı İbrahim Çeçen University.

\section{Findings}

Based on the results of monitoring the game activity of children of the middle pre-school age, we grouped the causes of conflicts according to the classification proposed by the scientists Ia. L. Kolominskii and B. P. Zhiznevskii:
Table 1. Causes of conflict

\begin{tabular}{ccccc}
\hline The Causes & \multicolumn{2}{c}{ Girls } & \multicolumn{2}{c}{ Boys } \\
\hline Because of roles & $\mathrm{f}$ & $\%$ & $\mathrm{f}$ & $\%$ \\
\hline Regarding the correctness of game actions & 18 & 75 & 12 & 60 \\
\hline Because of toys & 10 & 42 & 8 & 44 \\
\hline Because of team composition & 6 & 25 & 6 & 33 \\
\hline Because of game plot & 6 & 25 & 8 & 44 \\
\hline Because of game collapse & 5 & 20 & 13 & 72 \\
\hline Regarding the choice of common game & 5 & 20 & 5 & 27 \\
\hline
\end{tabular}

Using the method of observation over children of 5-6 years, we make the following conclusion: most often conflicts at this age arise because of the roles and regarding the correctness of game actions. It should also be noted that conflicts among girls are more frequent than among boys. It is interesting that the conflict because of the game collapse is more common among boys than girls.

To study the child's attitude to the conflict situation, questions were prepared. The questions are given below in Table 2. The conversation was accompanied by clarifying questions supplementing the answers of the children.

Table 2. Attitude of a child to conflict situation

\begin{tabular}{cccccccc}
\hline & \multicolumn{3}{c}{ Girls (\%) } & \multicolumn{3}{c}{ Boys (\%) } \\
\hline & Yes & No & Sometimes & Yes & No & Sometimes \\
\hline How often you quarrel with peers? & 44 & 34 & 22 & 48 & 38 & 14 \\
\hline Do you like this state, these feelings? & 2 & 96 & 2 & 5 & 92 & 3 \\
\hline
\end{tabular}

Table 3. Content of the answers of children about conflict situations

\begin{tabular}{ccc}
\hline 1. Why does the quarrel occur? & Girls (\%) & Boys (\%) \\
\hline Because of roles & 36 & 29 \\
\hline Because of the rules of game & 28 & 32 \\
\hline Because of bad words & 13 & 26 \\
\hline Because of slandering & 15 & 7 \\
\hline Because of domineering & 18 & 19 \\
\hline How usually quarrels end? & & 21 \\
\hline Ge apologize to each other & 46 & 13 \\
\hline We complaint to teacher & 53 \\
\hline We fight & 31 & 8 \\
\hline What kind of feelings you have, when you are involved in a quarrel? & 0 & 61 \\
\hline I get angry & & 33 \\
\hline I scream & 46 \\
\hline I resent & 24 \\
\hline I cry & 36 \\
\hline I run to teacher or mother & 22 \\
\hline Throw toys & 4 \\
\hline
\end{tabular}


As seen in the table, children are negative about conflict situations, but at the same time they admit that a quarrel does occur and it is a nuisance $(96 \%$ and $92 \%)$. Conflict situations often end the game (46\%), girls easily ask each other for forgiveness, and boys (8\%) can sometimes fight. Psychological state is also important during the conflict, so anger $(46 \%$ and $61 \%)$ and resentment (36\% and $12 \%)$ prevail among children.

According to observations of conflict situations, the outcome of this problem was important, that is, the ways to resolve conflict situations by children without adults' involvement. The conclusion of conflict resolution methods is given in Table 4 .

Table 4. Methods to resolve conflict situations

\begin{tabular}{ccc}
\hline & $\begin{array}{c}\text { Girls } \\
(\%)\end{array}$ & $\begin{array}{c}\text { Boys } \\
(\%)\end{array}$ \\
\hline $\begin{array}{c}\text { Psychological exposure (cry, scream, stamp } \\
\text { feet) }\end{array}$ & 67 & 9 \\
\hline $\begin{array}{c}\text { Verbal exposure ("Give", "Leave", "I am the } \\
\text { teacher") }\end{array}$ & 47 & 13 \\
\hline $\begin{array}{c}\text { Threating ("I'll tell to teacher", "I'm no } \\
\text { longer friends with you") }\end{array}$ & 36 & 7 \\
\hline $\begin{array}{c}\text { Arguments ("You cannot play", "This is } \\
\text { mine!") }\end{array}$ & 26 & 11 \\
\hline Physical exposure (push each other, fight) & 7 & 21 \\
\hline
\end{tabular}

As seen in the table, mainly girls are resorting to "psychological" (67\%) and "verbal" (47\%) exposures. Boys in conflict situations take tough "arguments" (11\%) and "physical" impact (21\%). Boys and girls resort to such "threats" as "I will not play with you anymore," "I will never share a toy with you," "I'll tell the teacher everything," etc. Completion of the conflict situation for both girls and boys of 5-6 years is instantaneous, accompanied by loud cries or the use of physical strength.

\section{Results and Discussion}

Conflict situation develops into conflict only with the joint actions of peers. A similar situation arises in cases when there is a contradiction: between the demands of peers and the objective capabilities of children in the game. In both cases it is a question of the unformed leading game activity of pre-school children, which contributes to the development of psychological conflict. The reasons may be the insufficient initiative of the child in establishing contacts with peers, the absence of emotional aspirations between the players, when, for example, the desire to command prompts the child to leave the game with his beloved companion and enter into a game with a less pleasant but pliable peer, lack of communication skills. As a result of such interactions, two types of contradictions may arise: the discrepancy between the requirements of peers and the objective capabilities of the child in the game and the mismatch in the motives of playing of a child and peers [15].
Psychological studies identify factors that affect the aggressive behavior of children. Among these factors, the characteristics of family guidance, examples of aggressive behavior that the child observes in television or from peers, the level of emotional tension and frustration, etc. are usually emphasized. However, it is obvious that all these factors cause aggressive behavior not in all children, but only in a certain part. In the same family, under similar conditions of guidance, children of different degrees of aggressiveness grow up. It can be assumed that already at the pre-school age the certain internal prerequisites that promote aggressiveness develop, that children who are prone to violence differ significantly from their peace-loving peers not only in their external behavior, but also in their psychological characteristics. The study of these characteristics is extremely important for understanding the nature of this phenomenon and for the timely overcoming of dangerous trends. To identify the psychological characteristics that distinguish aggressive children, it is necessary to compare them with the same characteristics of pre-school children who do not show a tendency to aggression [20].

As shown by the researchers, the largest number of conflicts is conflicts about the distribution of roles, as well as the correctness of gaming. This result coincides with the studies of Ia. L. Kolominskii and B. P. Zhiznevskii. The authors identified typical causes of conflicts between children of different ages, where between children of older pre-school age conflicts most often arise because of the distribution of playing roles, as well as about the correctness of game actions.

According to the results of the "child's attitude to the conflict situation," it should be noted that children (48\%) agree that they often quarrel with their peers and they do not like conflict situations (96\%) and what they feel during a quarrel. This is an indicator that children know that it is not good to swear, fight, and scream.

To the question "How do your quarrels end?" $46 \%$ of the girls answered "the game is over", that is, the conflict situation affects the development of the game and the overall psychological state of the participants in the game. $53 \%$ of girls in conflict situations apologize for each other and thus continue the game. These children express the opinion that "if we quarrel we will not be able to play further." This solution is considered beneficial for children to enjoy the game together.

To the question "What feelings do you feel when you are involved in a quarrel?" children expressed negative feelings (get angry, shout, resent, cry, throw toys), that is conflict situations cause only negative emotions for children.

Approaches to resolve conflict situations are mostly "verbal" (47\%) and "psychological" (67\%) for girls and boys there is a "physical impact" (21\%) pushing, selecting, throwing, etc. "Threats" and "arguments" such as "this is mine!", "I will not play with you anymore", "I'll tell the 
teacher everything," etc. are used by both girls and boys during conflict resolution.

In general, it cannot be judged only by external manifestations about conflict actions, about aggressiveness, it is necessary to know the motives and the accompanying experiences. The identification of the motives for the aggressive behavior of children, the study of their psychological conditions and options is urgently needed both for the timely diagnosis of this phenomenon and for the development of corrective programs [21].

Analysis of the approaches of various authors allowed us to determine the following psychological and pedagogical conditions for preventing conflict behavior in children of senior pre-school age:

- the use in the work with children of a complex of interactive games aimed at building their cohesion and cooperation, teaching effective methods of communication, forming a claim for social recognition and conflict resolution between children;

- playing the conflict situations and modeling the way out of them;

- creation of special conditions aimed at developing children's ability to adequately respond to conflict and rationally resolve conflict situations, as well as systematic work with teachers to teach them the ability to analyze children's conflicts and prevent them.

\section{REFERENCES}

[1] Smirnova E., O., Holmogorova V., M. (2010). Konfliktnye deti. M.

[2] Vygotski, L., S. (1983). Somplete Set of Works. Volume, 3

[3] Vygotski, L., S. (1966). Igra i ee rol' v psihicheskom razvitii rebenka. Voprosy psihologii, 6.

[4] Zaporozhec, A., V. (1986). Selected Psychological Works, Volume, 3

[5] Leontev, A., N. (1983). Izbrannye Psihologicheskie Proizvedeniya: M.: T. 2

[6] Morozov, A., V. (2000). Delovaya Psihologiya. M.: Soyuz.

[7] Shedrovicki, G., B. (1995). OrganizacionnoDeyatelnostnaya Igra kak Novaya Forma Organizacii i Metod Razvitiya Kollektivnoi Misledeyatelnosti. M.

[8] Iakobson, S., G. (1984). Psihologicheskie Problemy
Eticheskogo Razvitiya Detei. M.

[9] Royak, A., A. (1988). Psihologicheski Konflikt i Osobennoesti İndividualnogo Razvitiya Lichnosti Rebenka. M.

[10] Ancupov, A.,Ia. Shipilov, A.,I. (2000). Konfliktologiya. M.: Yuniti

[11] Kolominski, Ia.,L., Zhiznevski, B.,P. (1986). Socialno-Psihologicheskie Osobennosti Sovmestnoi Igrovoi i Trudovoi Deyatelnosti Doshkolnikov. Voprosy Psihologii, $5,38-44$

[12] Anzharov, A., I. (1975). Osobennosti Obsheniya Starshih Doshkol'nikov so Sverstnikami. Doshkol'noe Vospitanie, 10, 25-30

[13] Kalinina, R., R. (2001). Trening Razvitiya Lichnosti Doshkolnika: Zanyatiya, Igry, Uprazhneniya. M. Rech

[14] Bozhovich, L. (1995). Problemy Formirovaniya Lichnosti. Voronehz.

[15] Elkonin, D., B. (2009). Psihologiya Igry. M.

[16] Galiguzova, L., N. (2000). Psihologicheski Analiz Fenomenologii Detskoi Zastenchivosti. Voprosy Psihologii.

[17] Smirnova, E., O., Ermolova, T., V., Mesheryakova, S.,Yu. (2008). Razvitie Predmetnoi Deyatelnosti i Poznavatelnyh Sposobnostei. M.: Mozaika-Sintez

[18] Huhlaeva, O., V. (2003). Korrekciya Narusheni Psihologicheskogo Zdorovya Doshkolnikov i Mladshih Shkolnikov. M: Akademiya, ISBN 5-7695-1238-5

[19] Pasechnik, L. (2007). Trevozhni Rebenok. Doshkolnoe Vospitanie. 9

[20] Smirnova,http://docplayer.ru/26029592-E-o-smirnova-agres sivnye-deti-psihologicheskie-osobennosti-i-individualnye-v arianty.html

[21] Smirnova, http://docplayer.ru/26029592-E-o-smirnova-agre ssivnye-deti-psihologicheskie-osobennosti-i-individualnyevarianty.html

[22] Koh, I.,A. (1997). Konflikty i ih Regulirovanie. Ekaterinburg

[23] Fopel, K. (2003). Kak Nauchit Detei Sotrudnichat Psihologicheskie Igry i Uprazhneniya: Prakticheskoe Posobie. M.: Genezis

[24] Smirnova E., O., Holmogorova V., M. (2005). Mezhnichnostnye Otnosheniya Doshkol'nikov: Diagnostika, Problemy, Korrekciya. M.: Vlados

[25] Smirnova, E., O. Huzeeva, G., P. (2005). Psihologicheskie Osobennosti i Varianty Detskoi Agressivnosti. Voprosy Psihologii, 1 